Article

\title{
Assessment of Progressive Collapse Resistance of Steel Structures with Moment Resisting Frames
}

\author{
Osama Mohamed * (D) and Rania Khattab \\ College of Engineering, Abu Dhabi University, Abu Dhabi 59911, UAE; r.nabil-adjunct@adu.ac.ae \\ * Correspondence: osama.mohamed@adu.ac.ae; Tel.: +971-50-180-0767
}

Received: 17 December 2018; Accepted: 3 January 2019; Published: 9 January 2019

\begin{abstract}
This paper evaluates the practice of using moment connections in the perimeter of the structural system and shear connections within the interior connections of the three-dimensional structural system from the perspective of resistance to progressive collapse. The enhanced resistance to progressive collapse associated with using moment resisting connections at the perimeter as well as internal to the three-dimensional system is assessed. Progressive collapse occurrence and system resistance are determined using the alternate path method which presumes a primary load carrying-member is notionally removed. The paper compares the structural response determined using linear elastic, non-linear elastic and non-linear dynamic analyses. Linear and non-linear static analyses are found to be incapable of capturing the response pursuant to the loss of the primary load carrying member. The analysis procedures used in this study followed (for the most part) the United States Department of Defense Guide for Progressive Collapse Resistant Design of Structures.
\end{abstract}

Keywords: alternate path method; moment resisting connections; shear connections; non-linear dynamic analysis

\section{Introduction}

It is well known that moment resisting connections are more expensive to build and require special expertise compared to shear connections; therefore, from an economic perspective, they should be used sparingly in steel framed structures. A popular structural configuration in professional practice employs moment resisting frames at the perimeter of the three-dimensional structural system along with limited, if any, moment connections within the interior of the building structure. The purpose of this paper is to examine the progressive collapse response of steel structural systems when moment resisting frames are used only in the perimeter of a regular steel frame, compared to the response when additional moment frames are used within the interior part of the building. The progressive collapse response was assessed using linear elastic, non-linear elastic, and non-linear dynamic analyses, and the results were compared. The analysis procedures in this paper followed (for the most part) the United States Department of Defense (DoD) guidelines for Design of Buildings to Resist Progressive Collapse [1]. Progressive collapse resistant design, including the Alternate Path (AP) method, is addressed in various codes and standards [2]. Dinu et al. [3] conducted an experimental study validated with an analytical model for the progressive analysis of steel frame structures with moment resisting frames in two perpendicular directions. Piluso et al. [4] proposed a method that represents the probabilistic version of the Theory of Plastic Mechanism Control (TPMC), and applied it to moment resisting frames. The authors developed a relationship to compute the over-strength factor needed to account for the effect of material variability in the application of TPMC. 


\section{Theoretical Background and Review of Progressive Collapse Literature}

The Alternate Path (AP) method is used to assess the capability of the structural system to transfer gravity loads through an alternate path pursuant to the loss of a primarily load-carrying element. Columns are the most critical structural elements and $\mathrm{DoD}[1]$ requires framed structural systems to possess the strength, stiffness, and redundancy necessary to transfer loads after the loss of corner, exterior, and interior columns.

Corner columns are particularly vulnerable as the structural system may cantilever for a long distance, leading to significant demand and twisting deformations, particularly on external frames, which may exacerbate the deformation response [5].

The AP method, which presumes that progressive collapse is gravity-driven, permits structural responses to be determined using linear static procedures (LSP), non-linear static procedures (NSP), or non-linear dynamic procedures (NDP). The AP method is notoriously hazard independent but accepted almost universally to assess the progressive collapse capacity of structural systems. Several studies were conducted and documented in the literature where progressive collapse was assessed for specific hazards such as vehicular impact [6].

The assessment of progressive collapse potential in steel building structures using the AP method is sensitive to the modelling assumptions [7]. For example, analysis results are sensitive to whether or not the floor system is included in the model, analysis and modelling approaches used, type of steel constitutive model, and model selected to represent the beam-to-column connection.

Creating a global model for progressive collapse assessment of building structures using non-linear dynamic analysis is the most reliable approach to capture the structural response. However, it is computationally expensive, requiring several days for simple models using multiple processors [8].

Kim and Kim [9] developed an integrated system for progressive collapse analysis capable of detecting the damage level during an iterative solution and constructed the modified structural system during each step of the solution. However, the investigators discussed two-dimensional (2D) systems, which are not capable of capturing 3D effects such as torsion [1].

\section{Case Study}

Typically, progressive collapse resistance is assessed after the structural system is designed for applicable design codes. The case study building examined in this paper is first designed in accordance using the Load and Resistance Factor Design (LRFD) method [10], and then checked for progressive collapse resistance.

\subsection{Structural System Designed Using Load and Resistance Factor Design (LRFD) Method}

The case study steel structure was developed for two purposes: (1) to assess the implications of using moment resisting frames on the progressive collapse response, and (2) to understand the effect of analysis method on the structural response. The fifteen-story case study building is considered regular as defined in Section 3-2.11.1.1 [2], which permits the use of the linear elastic analysis method. The framed steel structure consists of $7 \times 5$ panels on floor plan view. The structural configuration for both plan and elevation locations are shown in Figures 1 and 2. The exterior and interior spans along the $\mathrm{x}$-axis are $8 \mathrm{~m}$ and $10 \mathrm{~m}$, respectively, whereas the exterior and interior spans along the y-axis are $8 \mathrm{~m}$ and $12 \mathrm{~m}$, respectively. 


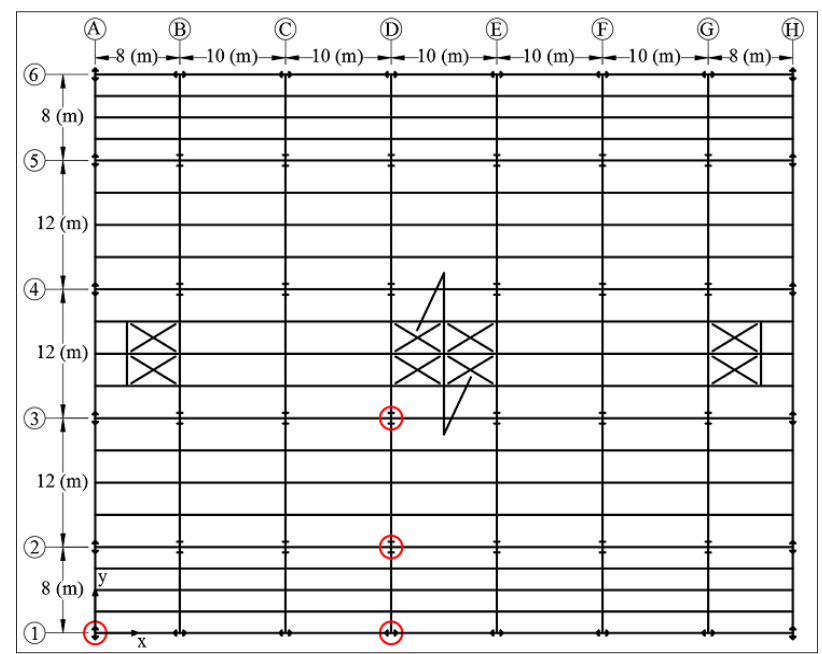

Figure 1. Plan view of the fifteen-story steel-framed building.

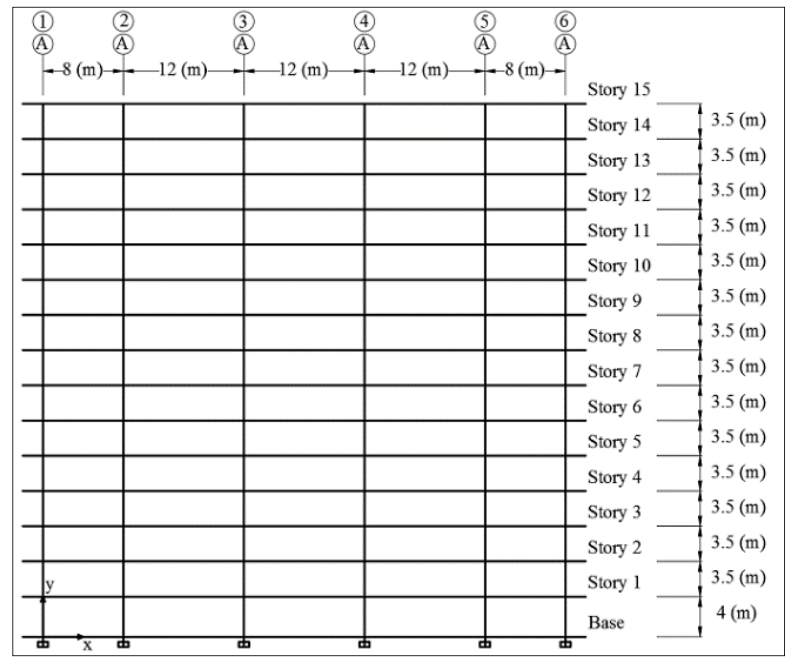

Figure 2. Building elevation at grid line A.

The four columns circled in Figure 1 are assumed to be notionally removed alternately at the lowest building level to assess the capacity of the structural system to transfer loads.

The structural elements were sized for a reducible live load (including allowance for light weight partitions) of $3.6 \mathrm{kN} / \mathrm{m}^{2}$, a perimeter cladding load of $3.2 \mathrm{kN} / \mathrm{m}$, a floor self-weight (normal weight concrete on filled slab steel deck) of $2.729 \mathrm{kN} / \mathrm{m}^{2}$, and a superimposed dead load of $4 \mathrm{kN} / \mathrm{m}^{2}$. The composite floor slab is considered in this study as gravity load on the structural framing system and its effect on mitigating progressive collapse is conservatively ignored. Composite steel-concrete floor systems typically enhance the resistance of the primary structural steel system to progressive collapse [11].

Wind load parameters for the case study examined in this paper were defined in accordance with ASCE 7-10 [12] and were assumed to control seismic load combinations. The assumed exposure category for wind analysis is B, and the design wind speed is $100 \mathrm{~m} / \mathrm{h}(161 \mathrm{~km} / \mathrm{h})$.

Based on the mapped acceleration parameters of the ground motion record, the case-study building is assigned to seismic design category (SDC) A in accordance with ASCE 7-10 [12]. Therefore, no special design requirements are specified for moment frames and their connections. In this respect, Cassiano et al. [13] argued that if connections are not designed to support beam catenary action, then the strong beam/weak column approach inherent in wind design provides better progressive collapse resistance compared to seismic design. 
Table 1 summarizes the main structural specifications for the floor, connection, and framing elements. Specifications for steel sections are based on the American Society for Testing and Materials (ASTM) A6.

Table 1. Structural specifications for floor, connections, and framing elements.

\begin{tabular}{|c|c|c|}
\hline Floor System & $\begin{array}{c}\text { Main Structural Framing } \\
\text { Elements }\end{array}$ & Connections \\
\hline \multirow[t]{2}{*}{$\begin{array}{l}\text { Normal wt, depth }=152 \mathrm{~mm} \\
\text { 28-day strength: } 30 \mathrm{MPa}\end{array}$} & \multirow{2}{*}{$\begin{array}{l}\text { ASTM A992 W-shape } \\
\text { Yield strength }\left(\mathrm{F}_{\mathrm{y}}\right)=345 \mathrm{MPa} \\
\text { Secondary beams designed as } \\
\text { composite with floor slab. }\end{array}$} & $\begin{array}{l}\text { Flexible shear tab: } \\
\text { Plate thickness: } 9.5 \mathrm{~mm}(3 / 8 \text { inch)Depth } \\
\text { of bolt group }\left(\mathrm{d}_{\mathrm{bg}}\right)=228 \mathrm{~mm}(9 \text { inch })\end{array}$ \\
\hline & & $\begin{array}{l}\text { Moment connections: } \\
\text { Improved unreinforced welded flange } \\
\text { with bolted web }\end{array}$ \\
\hline
\end{tabular}

Analysis and design were conducted using AISC [10]. The direct analysis method and second-order effects were accoutned for using the AISC [10] general second-order method. The LRFD method was used to determine demand and capacity. Analysis and initial design were conducted using the structural design program ETABS, produced by CSI America Inc., California, USA [14]. Three-dimensional models were created for analysis and design, as well as for assessing the potential for progressive collapse as discussed in a subsequent section of this paper. Three-dimensional models are more capable of predicting the response of structural systems [15].

Two configuations were considered: (1) moment resisting frames at the perimeters and shear connections to connect internal beams to columns, and (2) moment resisting frames at the perimeters as well as internally along grid lines B, C, D, E, F, and G (see Figure 1), and gravity beams with shear connections elsewhere. Whenever gravity beams are defined, they are analysed and designed as composite with the deck. Figures $3-5$ show the wide-flange (w-shapes) sections that passed all AISC [10] requirements under the loads covered in this section.

1. $\mathrm{W} 530 \times 138$

2. W360 x 196

$3 \quad \mathrm{~W} 360 \times 262$

(4) W360 287

5. W360 × 314

$6 \mathrm{~W} 360 \times 382$

7 $W 360 \times 592$

8 W360 × 551

9 W360 x 509

$10 \mathrm{~W} 360 \times 347$

\begin{tabular}{|c|c|c|c|c|c|c|c|c|c|}
\hline (1) & & & 3 & & (4) & & & & \\
\hline & 1 & 1 & & 1 & & 1 & & $1]$ & Story 15 \\
\hline 2 & 113 & 1 & 2 & & 2 & 1 & 3 & 11 2 & Story 14 \\
\hline 2 & 113 & 1 & 2 & & 2 & 1 & 3 & 112 & Story 13 \\
\hline 2 & 13 & 1 & 2 & 1 & 2 & 1 & 3 & 112 & Story 12 \\
\hline 司 & 13 & 1 & 2 & 1 & 2 & 1 & 3 & 12 & - Story 11 \\
\hline 2 & 13 & 1 & 2 & & 2 & 1 & 3 & 1 . 2 & Story 10 \\
\hline 2 & 1 . 3 & 1 & 4 & 1 & 4 & 1 & 3 & 11 . & Story 9 \\
\hline 2 & 113 & 1 & 3 & 1 & 3 & 1 & 3 & 11 2 & _ Story 8 \\
\hline 2 & 14 & 1 & 5 & & 5 & 1 & 4 & 11 2 & Story 7 \\
\hline 2 & 14 & 1 & 10 & & 10 & 1 & 4 & 114 & Story 6 \\
\hline 2 & 15 & 1 & 5 & 1 & 5 & 1 & 5 & 114 & Story 5 \\
\hline 2 & 110 & 1 & 9 & 1 & 9 & 1 & 10 & 11 4 & Story 4 \\
\hline 3 & 116 & 1 & 9 & 1 & 9 & 1 & 6 & 1 . 3 & Story 3 \\
\hline 3 & 11.7 & 1 & 9 & 1 & 9 & 1 & 7 & 1 . 4 & Story 2 \\
\hline 3 , & 17 & 1 & 8 & 1 & 8 & 1 & 7 & 110 & _Story 1 \\
\hline है & 7 & & 7 & & 7 & & 77 & 10 & Base \\
\hline
\end{tabular}

Figure 3. Designed sections for frames at elevations A and $\mathrm{H}$. 


\begin{tabular}{|c|c|c|c|c|c|c|c|c|c|}
\hline & (1) & 1 & 1 & 1 & 1 & 1 & 1 & & Story 15 \\
\hline & 2 & $1]$ & $\begin{array}{lll}1 & 2 \\
\end{array}$ & $\begin{array}{|ll|}1 & 2 \\
\end{array}$ & \begin{tabular}{ll|}
1 & 2 \\
\end{tabular} & \begin{tabular}{ll|}
1 & 2 \\
\end{tabular} & \begin{tabular}{ll|}
1 & 2 \\
\end{tabular} & 10 & Story 14 \\
\hline $1 \mathrm{~W} 610 \times 113$ & 2 & $1][2$ & $\begin{array}{lll}1 & 2 \\
\end{array}$ & $\begin{array}{|ll|}1 & 2 \\
\end{array}$ & $\begin{array}{ll}1 & 2 \\
\end{array}$ & $\begin{array}{ll}1 & 2 \\
\end{array}$ & $\begin{array}{ll}1 & 2 \\
\end{array}$ & 12 2 & Story 13 \\
\hline (2) W360 × 196 & 2 & $1 \sqrt{2}$ & 1] 2 & $\begin{array}{ll}1 & 2 \\
\end{array}$ & $\begin{array}{ll}11 & 2 \\
\end{array}$ & $\begin{array}{ll}1 & 2 \\
\end{array}$ & $\begin{array}{ll}1 & 2 \\
\end{array}$ & 1 [ 2 & Story 12 \\
\hline (3) W360 × 382 & 2 & $1] \quad 2$ & $\begin{array}{ll}11 & 2 \\
\end{array}$ & $\begin{array}{|ll|}1 & 2 \\
\end{array}$ & $\begin{array}{ll}1 & 2 \\
\end{array}$ & $\begin{array}{ll}1 & 2 \\
\end{array}$ & $\begin{array}{ll}1 & 2 \\
\end{array}$ & 12 & Story 11 \\
\hline (4) W360 $\times 314$ & 2 & 112 & $\begin{array}{ll}1 & 2 \\
\end{array}$ & $\begin{array}{ll}1 & 2 \\
\end{array}$ & \begin{tabular}{ll|}
1 & 2 \\
\end{tabular} & \begin{tabular}{ll|}
1 & 2 \\
\end{tabular} & $\begin{array}{|ll|}1 & 2 \\
\end{array}$ & 1 2 2 & Story 10 \\
\hline $6 \mathrm{~W} 360 \times 382$ & 2 & 112 & $\begin{array}{lll}1 & 7 \\
\end{array}$ & $\begin{array}{ll}1 & 7 \\
\end{array}$ & $\begin{array}{ll}1 & 7 \\
\end{array}$ & $\begin{array}{lll}1 & 7 \\
\end{array}$ & $\begin{array}{ll}1 & 2 \\
\end{array}$ & 12 & Story 9 \\
\hline (7) W360 × 262 & 2 & $11 \quad 3$ & $\begin{array}{ll}1 & 7 \\
\end{array}$ & 113 & $1 \quad 7$ & $\begin{array}{ll}1 & 7 \\
\end{array}$ & $\begin{array}{ll}1 & 7 \\
\end{array}$ & 113 & Story 8 \\
\hline $8 \mathrm{~W} 360 \times 347$ & 2 & $1 \underline{3}$ & 18 & 113 & $\begin{array}{ll}1 & 6 \\
\end{array}$ & $\begin{array}{ll}1 & 6 \\
\end{array}$ & $\begin{array}{ll}1 & 6 \\
\end{array}$ & 113 & Story 7 \\
\hline 9 W360 x 421 & 2 & $1]$ & 18 & $11 \quad 4$ & $\begin{array}{ll}1 & 6 \\
\end{array}$ & $\begin{array}{|ll|}1 & 6 \\
\end{array}$ & $\begin{array}{ll}1 & 6 \\
\end{array}$ & 17 & Story 6 \\
\hline $10 \mathrm{~W} 360 \times 509$ & 2 & $1]$ & $\begin{array}{ll}11 & 6 \\
\end{array}$ & $\begin{array}{ll}1 & 6 \\
\end{array}$ & $\begin{array}{ll}1 & 6 \\
\end{array}$ & $\begin{array}{ll}1 & 6 \\
\end{array}$ & $\begin{array}{|ll|}1 & 6 \\
\end{array}$ & 114 & Story 5 \\
\hline $11 \mathrm{~W} 360 \times 551$ & 2 & 14 & $\begin{array}{ll}1 & 6 \\
\end{array}$ & $\begin{array}{ll}1 & 6 \\
\end{array}$ & $\begin{array}{lll}1 & 6 \\
\end{array}$ & $\begin{array}{|ll|}1 & 6 \\
\end{array}$ & $\begin{array}{|ll|}1 & 6 \\
\end{array}$ & 114 & Story 4 \\
\hline $12 W 360 \times 592$ & 毒 & 16 & $\begin{array}{ll}1 & 9 \\
\end{array}$ & 111 & $\begin{array}{ll}1 & 9 \\
\end{array}$ & 11 11 & 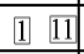 & 114 & Story 3 \\
\hline $14 \mathrm{~W} 360 \times 237$ & 3 & 115 & 110 & 111 & 111 & 111 & (1) 11 & (1) 13 & Story 2 \\
\hline & 3 & 15 & 1111 & 1111 & (1) 11 & (1) 11 & $\begin{array}{lll}1 & 11 \\
\end{array}$ & 113 & Story 1 \\
\hline & 5 & 5 & 12 & 11 & 11 & 11 & 11 & 8 & Base \\
\hline
\end{tabular}

Figure 4. Designed sections for frames at elevations 1 and 6.

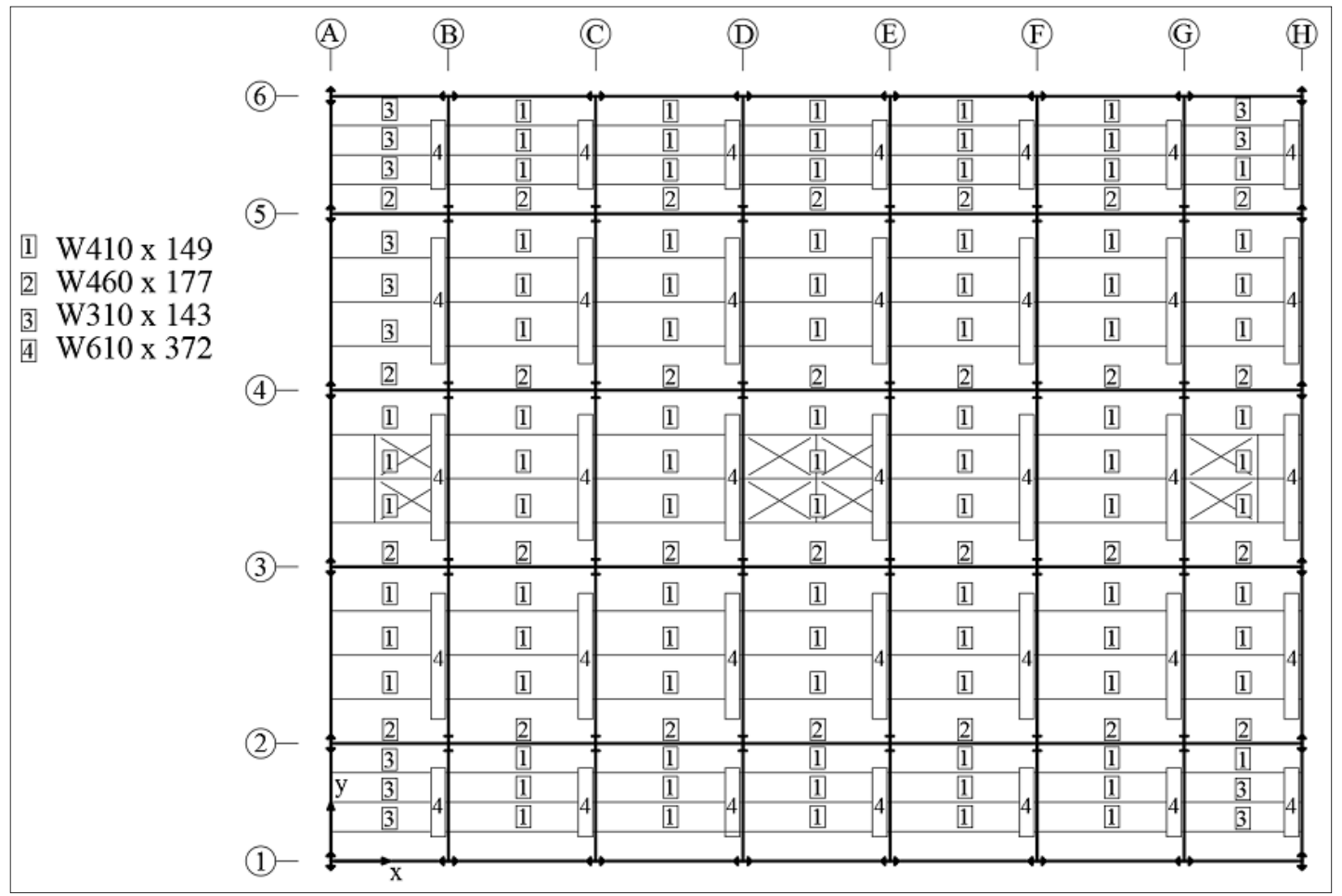

Figure 5. Designed sections for internal beams at all floor levels.

\subsection{Case Study Steel Structure Assessed For Progressive Collapse Resistance}

The structure designed in Section 3.1 of this paper is assessed for progressive collapse resistance in the following sections using the AP method. Three analysis methods were used for comparison purposes, namely: (1) linear static procedures, (2) non-linear static procedures, and (3) non-linear dynamic procedures. Emphasis is on the assessment of deformation-controlled actions. 
In order to determine deformation-controlled actions in AP linear or non-linear analyses, the gravity loads applied to the floor area adjacent to notionally removed columns at all floor levels is given by Equation (1).

$$
G_{L D}=\Omega_{L D}[1.2 D+(0.5 \text { or } 0.2 S)]
$$

where $G_{L D}=$ increased gravity loads for deformation-controlled actions for linear static analysis;

$D=$ dead load including façade loads $\left(\mathrm{kN} / \mathrm{m}^{2}\right)$;

$L=$ reduced live load $\left(\mathrm{kN} / \mathrm{m}^{2}\right)$;

$S=$ snow load $\left(\mathrm{kN} / \mathrm{m}^{2}\right)$; and

$\Omega_{L D}=$ load increase factor for deformation-controlled actions in linear and non-linear static analysis.

In linear and non-linear static analysis procedures for AP analysis, floor areas further from the notionally removed column are given by Equation (2).

$$
G=1.2 D+(0.5 \text { L or } 0.2 S)
$$

where $G$ = gravity loads.

\subsection{Parameters for Non-Linear Static and Dynamic Analyses}

The case study steel structural system is assessed for progressive collapse using non-linear static and non-linear dynamic methods. Post-yield behavior is simulated using concentrated moment-rotation plastic hinges that are permitted to form in flexural members at the ends and near the midspan. In columns, plastic hinges are caused by the interaction of axial forces and bending. Plastic hinges that account for the interaction of axial force and bending moment is represented by a 3D interaction (or yield) surface derived from AISC-LRFD equation H1-1a and H1-1b AISC [10]. Force-controlled actions are not permitted to form plastic hinges [1]. Torsion, a force-controlled action, leads to premature non-ductile failure [2]. Plastic hinge properties were adopted from ASCE 41, Seismic Rehabilitation of Existing Buildings [16].

The general configuration of the beam force-deformation relationship is shown in Figure 6 [1]. The rotation angles, $a$ and $b$, and the residual strength, $c$, depend on the cross-section used as shown in Table 2.

In order to demonstrate how the non-linear hinge properties for flexural members were calculated in the case study, the beams framing into the the notionally removed A1, shown in Figure 7, are examined. Welded unreinforced flange-bolted (WUF) moment connection are used for all moment resisting frames.

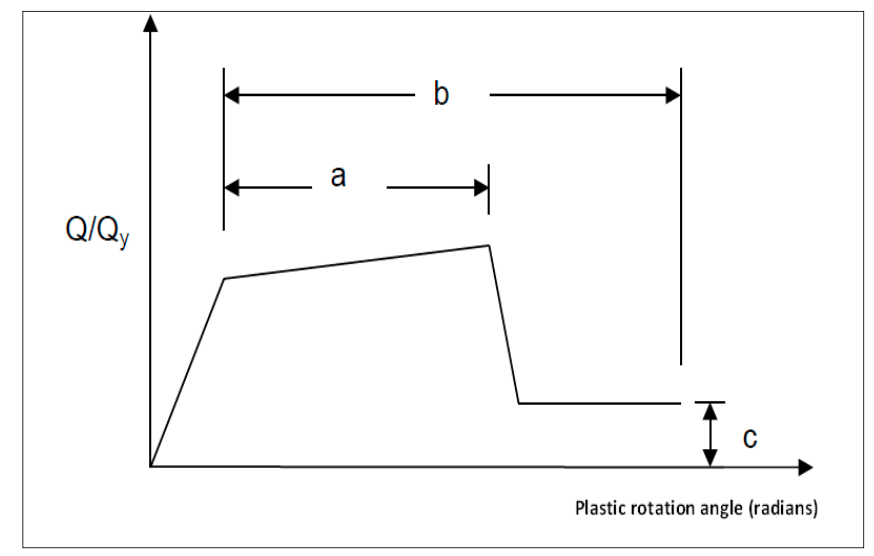

Figure 6. Force-rotation relationship for beam plastic hinges moment resisting frames [1]. 
Table 2. Acceptance citeria and plastic hinge parameters for beams framing into corner column A1.

\begin{tabular}{|c|c|c|c|c|c|c|}
\hline \multirow{3}{*}{$\begin{array}{c}\text { Beam } \\
\mathrm{mm} \times \mathrm{kg} / \mathrm{m} \\
(\mathrm{inch} \times \mathrm{Ib} / \mathrm{ft})\end{array}$} & \multicolumn{2}{|c|}{$\begin{array}{c}\text { Plastic } \\
\text { Rotation Angle }\end{array}$} & \multirow{3}{*}{$\begin{array}{c}\text { Residual } \\
\text { Strength Ratio }\end{array}$} & \multicolumn{3}{|c|}{ Acceptance Criteria } \\
\hline & & & & \multicolumn{3}{|c|}{ Plastic Rotation Angle (PRA) Radians } \\
\hline & a & $\mathbf{b}$ & & $\begin{array}{l}\text { Immediate } \\
\text { Occupancy }\end{array}$ & $\begin{array}{c}\text { Life } \\
\text { Safety }\end{array}$ & $\begin{array}{l}\text { Collapse } \\
\text { Prevention }\end{array}$ \\
\hline $\begin{array}{l}W 610 \times 113(W 24 \times 76) \\
W 530 \times 138(W 21 \times 93)\end{array}$ & $9 \theta_{y}$ & $11 \theta_{y}$ & $\begin{array}{l}0.6 \\
0.6\end{array}$ & $1 \theta_{y}$ & $\begin{array}{l}6 \theta_{y} \\
6 \theta_{1}\end{array}$ & $\begin{array}{l}8 \theta_{y} \\
8 \theta_{1}\end{array}$ \\
\hline
\end{tabular}

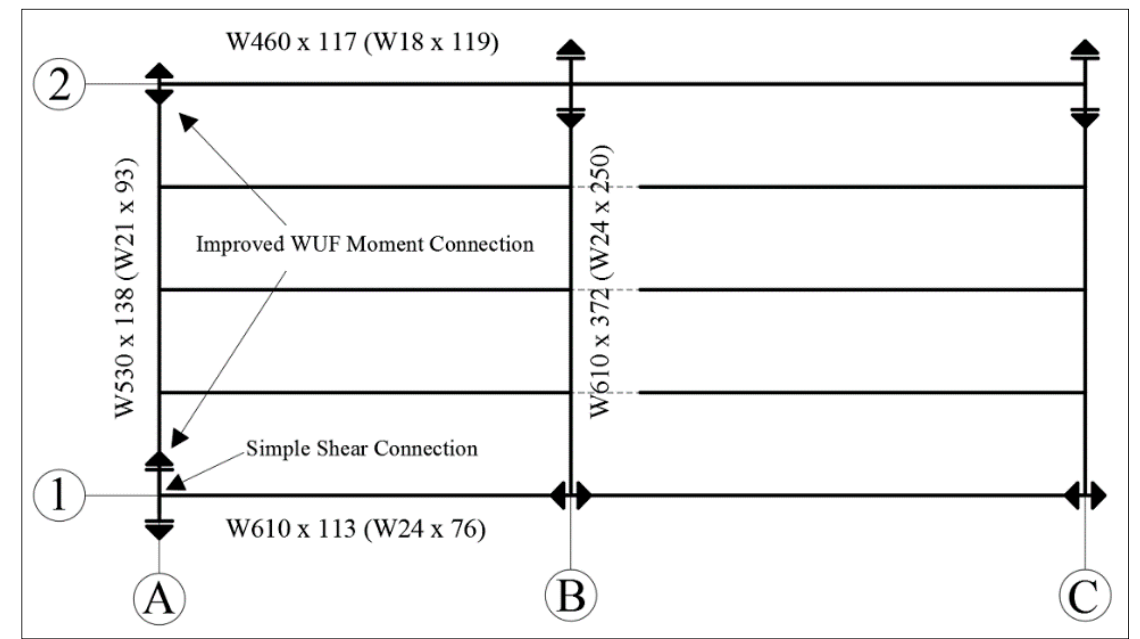

Figure 7. Partial plan view at the location where corner column A1 will be notionally removed at the base level.

The plastic hinge properties for the beams framing into column A1 are given in Table 2, which were adopted from ASCE 41 [16]. The acceptance criertia for members subjected to flexure only is chosen to ensure the prevention of collapse by eliminating brittle failure. The sections shown below were the two beams framing into column A1.

The yield rotation, $\theta_{y}$, is equal to $\frac{Z f_{y} l_{b}}{6 E I_{b}}$; where $I_{b}$ and $Z$ are the beam moment of inertia and the plastic section modulus about the major $x$-axis, respectively [1]. All analyses conducted in this study for the basic design as well as the progressive collapse assessment were carried out on three-dimensional models, but the effect of the floor system in resisting collapse was neglected conservatively. The contribution of slab to progressive collapse resistance is discussed in the literature [17].

\subsection{Load Increase Factors}

The load increase factor for deformation-controlled actions, $\Omega_{L D}$, defined in Equation (1), must be calculated for linear and non-linear static analyses. The process for calculating the load increase factor for linear static analysis is described in the literature [18]. The calculated load increase factor for linear static analysis is $\Omega_{L D}=2.67$.

For non-linear static analysis of steel structures, the load increase factor is given by Equation (3) [1]

$$
\Omega_{N}=1.08+\frac{0.76}{\frac{\theta_{p r a}}{\theta_{y}}+0.83}
$$


The permissible plastic rotation angle, $\theta_{\text {pra }}$, depends on connection type. Table 3 summarizes the calculated values of $\theta_{\text {pra }} / \theta_{y}$ for simple shear tabs and improved WUF with bolted web. These are needed to calculate the dynamic increase factor in Equation (3) to be used for non-linear static analysis.

Table 3. Calculation of $\theta_{\text {pra }} / \theta_{y}$ for determination of load increase factors in the panel adjacent to the notionally removed column A1.

\begin{tabular}{ccccc}
\hline Beam/Girder & $\begin{array}{c}\text { Yield Rotation Angle, } \\
\boldsymbol{\theta}_{\boldsymbol{y}} \text { (Radians) }\end{array}$ & $\begin{array}{c}\text { Simple Shear Tab } \\
\text { Connection }\left(\boldsymbol{\theta}_{\text {pra }}\right) \\
\text { (Radians) }\end{array}$ & $\begin{array}{c}\text { Improved WUF with } \\
\text { Bolted Web, } \boldsymbol{\theta}_{\text {pra }} \\
\text { (Radians) }\end{array}$ & $\left(\boldsymbol{\theta}_{\text {pra }}\right) /\left(\boldsymbol{\theta}_{\boldsymbol{y}}\right)$ \\
\hline $\mathrm{W} 530 \times 138(\mathrm{~A} 1-\mathrm{A} 2)$ & 0.0096627 & - & $0.021-0.0003 d=0.01452$ & 1.502686 \\
\hline $\mathrm{W} 610 \times 372(\mathrm{~B} 1-\mathrm{B} 2)$ & 0.00793126 & - & $0.021-0.0003 d=0.01311$ & 1.652953 \\
\hline $\mathrm{W} 460 \times 177(\mathrm{~A} 2-\mathrm{B} 2)$ & 0.0108276 & $0.0502-0.0015 \mathrm{~d}=0.0217$ & - & 2.0041375 \\
\hline $\mathrm{W} 610 \times 113(\mathrm{~A} 1-\mathrm{B} 1)$ & 0.0086196 & - & $0.021-0.0003 d=0.01383$ & 1.60448 \\
\hline
\end{tabular}

Therefore, the load increase factor for the bay immediately above the notionally removed corner column, A1, is, $\Omega_{N}=1.08+\frac{0.76}{\left(\frac{\theta_{p r a}}{\theta_{y}}\right)+0.83}=1.08+\frac{0.76}{(1.502686)+0.83}=1.405805$.

Similarly, the load increase factors columns D1, D2, and D3 are calculated and summarized in Table 4 for linear and non-linear static analyses.

Table 4. Load increase factors for linear and non-linear static analyses.

\begin{tabular}{ccc}
\hline Analysis & Linear Static & Non-Linear Static \\
\hline Corner column A1 & $\Omega_{L D}=2.67293$ & $\Omega_{N}=1.41$ \\
Interior column D2 & $\Omega_{L D}=2.67293$ & $\Omega_{N}=1.47$ \\
Interior column D3 & $\Omega_{L D}=2.67293$ & $\Omega_{N}=1.47$ \\
Edge column D1 & $\Omega_{L D}=2.67293$ & $\Omega_{N}=1.44$ \\
\hline
\end{tabular}

\subsection{Dynamic Analysis}

Non-linear dynamic analysis offers the advantage of providing a more realistic assessment of dynamic effects compared to the linear and non-linear static analysis. Linear and non-linear static analyses account for dynamic effects through the use of the load increase factor, $\Omega_{L D}$, discussed in the previous section of this paper. Nonetheless, dynamic analysis itself is sensitive to various assumptions including the time history function. The non-linear dynamic procedure for progressive collapse analysis is a very efficient method in which a primary structural element is removed dynamically and the structural material is permitted to undergo non-linear behavior. The evaluation and validation of the results can be time consuming. Non-linear dynamic analysis in this study assumes that the reaction at the notionally removed column is applied through a linear time history ramp function, reaching the full reaction value in four seconds. The time history functions used in dynamic analysis are not unique in terms of load duration. Kim et al. [19] proposed a function where the force is increased linearly in five seconds, then kept constant for two seconds.

\subsection{Moment Frames at Building Perimeter-Alternate Path Method}

In order to assess the progressive collapse resistance using the AP method, four columns at the lowest floor level were examined. Moment frames were applied at the perimeters of the structure only while internal gravity beams were connected to columns using shear connections. Although shear tab connections offer some contribution to progressive collapse resistance, such contribution is conservatively ignored in this study [20]. Cassian et al. [21] demonstrated that the contribution of bolted flush-end plate connections to progressive collapse resistance depends on several factors such as column orientation, the thickness of the end plate, the number of connection bolts/bolt diameter, etc. The notionally removed columns shown in Figure 1 include corner column A1, interior columns D2 
and D3, and edge column D1. The progressive collapse load case scenarios and correponding analysis methods are shown in Table 5. AP load combinations are described by Equations (1) and (2).

Table 5. Load cases to asses deformation-controlled actions when moment frames are used in building perimeters and shear connections are used internally.

\begin{tabular}{|c|c|c|c|c|}
\hline & Corner Column A1 & Interior Column D2 & Interior Column D3 & Edge Column D1 \\
\hline Linear static analysis & Load case 2 & Load case 5 & Load case 8 & Load case 11 \\
\hline Non-linear static & Load case 3 & Load case 6 & Load case 9 & Load case 12 \\
\hline Non-linear dynamic & Load case 4 & Load case 7 & Load case 10 & Load case 13 \\
\hline
\end{tabular}

\subsection{Moment Resisting Frames at Perimeter and Interior Grid Lines-Alternate Path Method}

In order to understand the effect of using interior moment resisting frames on deformationcontrolled responses, the case study was modified and additional moment resisting frames were added along grid lines B, C, D, E, F, and G. Gravity beams were connected to columns using shear connections. Critical columns that are notionally removed include a corner column, an edge column, and two interior columns. A total of 25 load cases were defined as shown in Table 6. The 25 load cases permit conducting linear static, non-linear static, and non-linear dynamic analyses for each each of the notionally removed columns.

Table 6. Load cases to asses deformation-controlled actions when moment frames are used in building perimeterw and internally along grid lines B, C, D, E, F, and G.

\begin{tabular}{ccccc}
\hline Anlysis Type & Corner Column A1 & Interior Column D2 & Interior Column D3 & Edge Column D1 \\
\hline Linear static analysis & Load case 14 & Load case 17 & Load case 20 & Load case 23 \\
Non-linear static & Load case 15 & Load case 18 & Load case 21 & Load case 24 \\
Non-linear dynamic & Load case 16 & Load case 19 & Load case 22 & Load case 25 \\
\hline
\end{tabular}

\section{Results and Discussion}

\subsection{Assessment of Structural Response When The Corner Column Is Notionally Removed}

This section outlines the analysis results when a corner column is removed and highlights the effect of using moment resisting frames interior and exterior to the building. This alternative is costlier than using moment frames at the perimeter only; however, it is more capable of transferring load carried by the notionally removed column to the rest of the structural system. The effect of the analysis method on the deformation response is also addressed in this section. Table 7 shows the summary of displacements and rotations at various locations and using different analysis methods. Vertical deformation at the location of column removal when assessed using non-linear dynamic analysis was the smallest compared to linear static and non-linear static analyses, which is consistent with findings reported in the literature [15]. This indicates that dynamic increase factors overestimate the response when used with linear and non-linear static analysis.

Figure 8 shows the deformation response at the location of the notionally removed column obtained through non-linear dynamic analysis for the frame when moment resisting frames are located in the perimeter of the building while shear connections are used internally. Figure 9 shows the deformation response at the location of the notionally removed column obtained through non-linear dynamic analysis for the case where moment resisting frames exist along the building perimeter as well as internally. Clearly, internal moment resisting frames succeeded in reducing the deformation response. In addition, moment resisting frames helped in reducing the overall lateral drift caused by the loss of the corner column. 
Table 7. Deformation response of the frame on gridline A obtained from AP analysis when corner column A1 is notionally removed.

\begin{tabular}{cccc}
\hline Load Case & $\begin{array}{c}\text { Displacement (mm) } \\
\text { Joint 14 Elevation A }\end{array}$ & $\begin{array}{c}\text { Displacement (mm) } \\
\text { Joint 21 Elevation A }\end{array}$ & $\begin{array}{c}\text { Rotation (Radian) } \\
\text { Joint 14 Elevation A }\end{array}$ \\
\hline 2 & -225.90 & -6.30 & 0.00960 \\
3 & -143.10 & -4.10 & 0.00676 \\
4 & -101.40 & -3.30 & 0.00508 \\
14 & -207.80 & -6.20 & 0.00810 \\
15 & -116.70 & -4.00 & 0.00466 \\
16 & -84.10 & -3.30 & 0.0034 \\
\hline
\end{tabular}

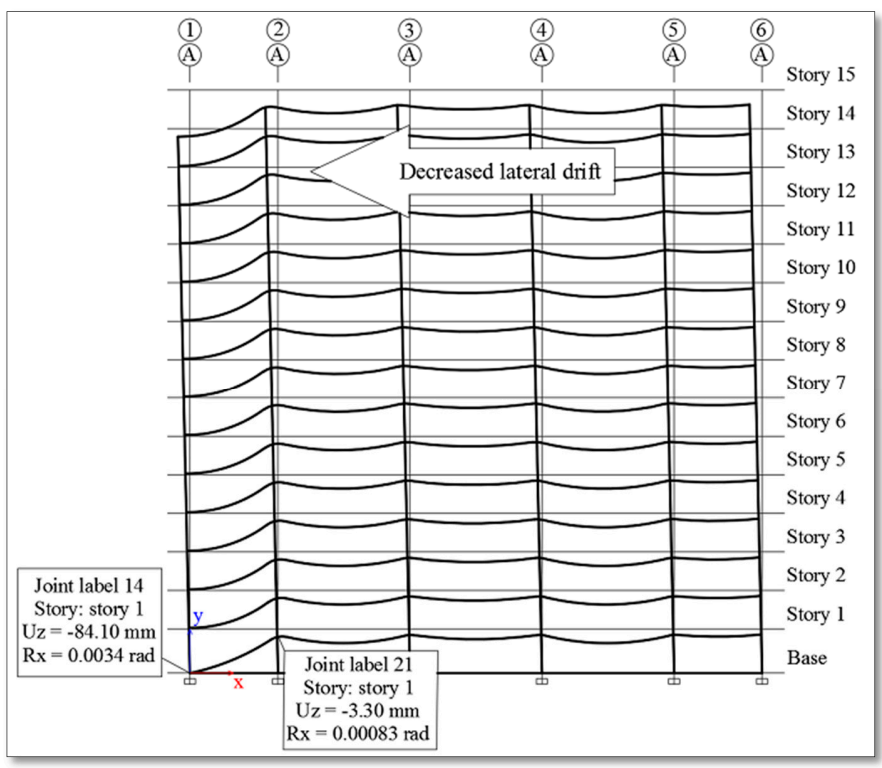

Figure 8. Deformation response of the structure at grid line A due to the notional removal of column A1 when moment frames are located at perimeters only (load case 4, non-linear dynamic analysis). $\mathrm{U}_{\mathrm{Z}}$ is the vertical deformation ( $\mathrm{mm}$ ) and $\mathrm{Rx}$ is the rotation (radians) about the $\mathrm{x}$-axis.

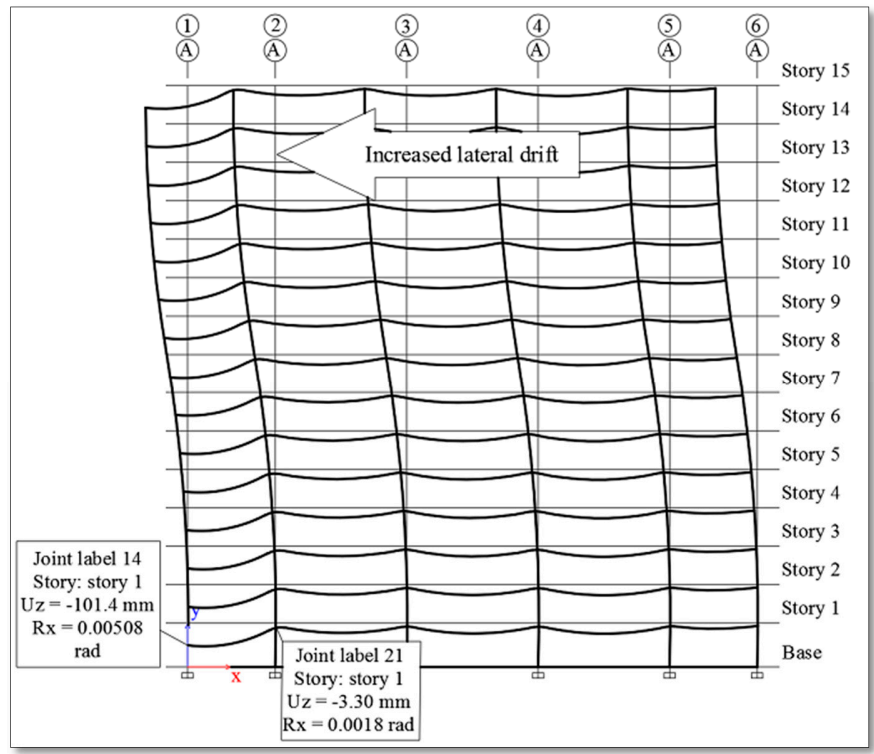

Figure 9. Deformation response of the structure at grid line A due to the notional removal of column A1 when moment frames are located at perimeters and along grid lines B, C, D, E, F and G (load case 16, non-linear dynamic analysis). 
The loss of corner columns renders panels that rely on them for support particularly vulnerable to disproportionate collapse since beams may end up cantilevering for long distances and be subjected to significant demand at the support point [22].

\subsection{Assessment of Structural Response When Internal Column Is Notionally Removed}

In order to evaluate the progressive collapse potential when an internal column is notionally removed, interior column D2 at the ground floor level was notionally removed and the system was analyzed. The responses when moment resisting frames were limited to the building perimeter in comparison to the responses when additional moment resisting frames were added are shown in Table 8. It can be seen that when moment resisting frames are used at the perimeters of the building, vertical deformations at the location of the notionally removed column did not converge, regardless of the analysis method. This is due to the incapability of the shear connections to sustain the large demand caused by the notional removal of the column. Therefore, it is not recommended to limit the usage of moment resisting frames to the perimeter of the building as it exacerbates progressive collapse in the event of the loss of an interior column. This may lead to the collapse of large floor panels supported by the failed column.

Table 8. Comparison between displacements and rotations when interior column D2 is notionally removed.

\begin{tabular}{ccccc}
\hline Load Case & $\begin{array}{c}\text { Displacement (mm) } \\
\text { Joint 33 Elevation D }\end{array}$ & $\begin{array}{c}\text { Rotation (Radians) } \\
\text { Joint 33 Elevation D }\end{array}$ & $\begin{array}{c}\text { Rotation (Radians) } \\
\text { Joint 17 Elevation D }\end{array}$ & $\begin{array}{c}\text { Rotation (Radians) } \\
\text { Joint 34 Elevation D }\end{array}$ \\
\hline 5 & Failure & -0.00378 & -0.0202 & 0.00112 \\
6 & Failure & -0.0000550 & -0.000411 & -0.000016 \\
7 & Failure & 0.0000270 & -0.000369 & 0.000050 \\
17 & -547.40 & -0.000664 & -0.0011 & 0.00302 \\
18 & -1342.60 & 0.0015 & -0.000111 & 0.000019 \\
19 & -212.10 & -0.000261 & -0.000417 & 0.000986 \\
\hline
\end{tabular}

Table 8 shows a comparison of displacements and rotations at the joint above the location of the removed column. When moment frames are used at the perimeter of the structure, the removal of internal column D2 leads to failure and the solution does not converge. However, when moment frames are used internally along grid lines B, C, D, E, F, and G, the solution predicts the deformation at the joint above the location of the removed column, with non-linear dynamic analysis being more capable of predicting the response.

Using non-linear dynamic analysis, Figure 10 shows that the deformation response at notionally removed column D2 did not converge when moment resisting frames were used at the perimeter only while shear connections were used internally. Figure 11 shows that non-linear dynamic analysis converges when moment resisting frames are applied at the permineter and along grid lines B, C, D, E, $\mathrm{F}$, and $\mathrm{G}$.

Figure 12 shows the deformation response using linear static analysis. The predicted deformation response using linear static analysis was $547.4 \mathrm{~mm}$ compared with non-linear dynamic analysis which predicted a much smaller deformation of $212.1 \mathrm{~mm}$. Figure 13 shows that non-linear static analysis predicted far more plastic hinges will form when a collapse occurs compared to non-linear dynamic analysis which predicted fewer hinges, as shown in Figure 11. Figure 13 shows how edge beams spaning from grid line D1 to grid line D3 are connected to the edge frame (grid line D1) using simple connections. This action decreases twising moment demand on beams located in perimeter frames. Note that torsion imposes additional demand on perimeter beams, which may reduce their plastic flexural capacity. This action is also practical since the beams connected to the perimeter frame are probably attached to the web of the column. 


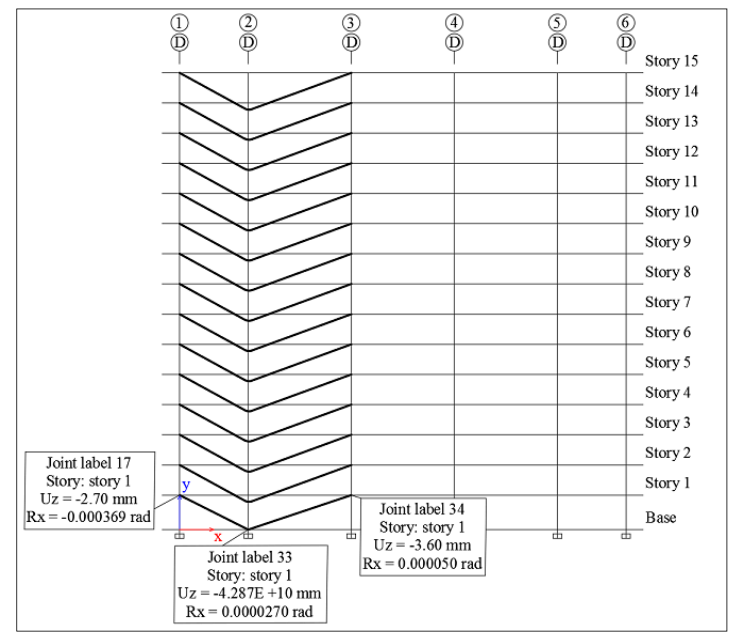

Figure 10. Displacement at notionally removed column D2 (part of grid line D) when moment frames are located at perimeters only (non-linear dynamic case 7).

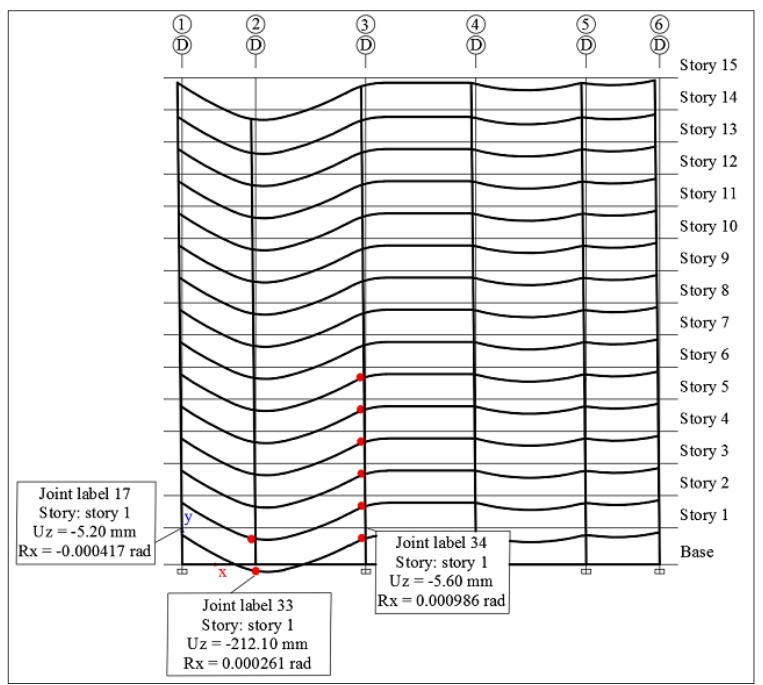

Figure 11. Displacement response at the location of removed column D2 when moment frames are located at perimeters and along grid lines B, C, D, E, F and G (non-linear dynamic case 19).

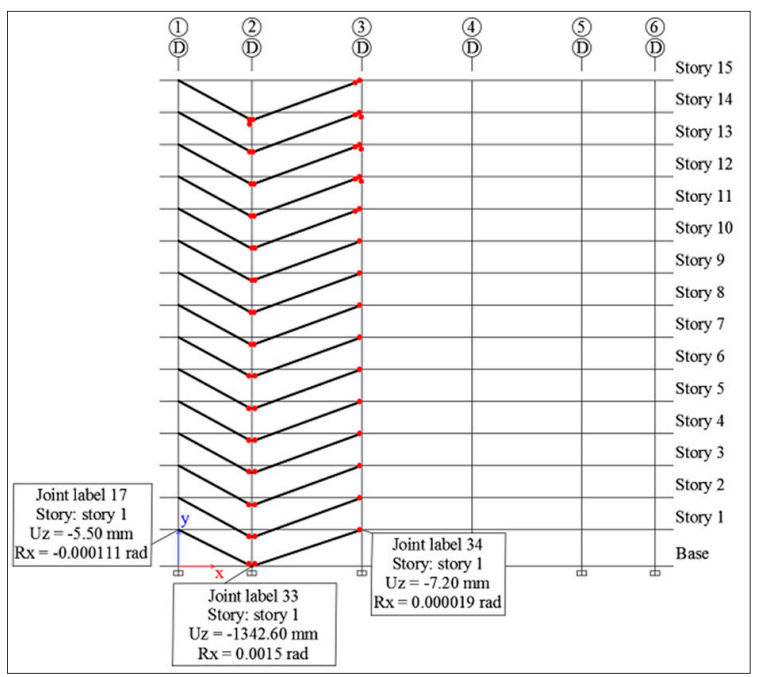

Figure 12. Displacement response at the location of the notionally removed column D2 when Moment frames are located at perimeters and along grid lines B, C, D, E, F and G (non-linear static case 18). 


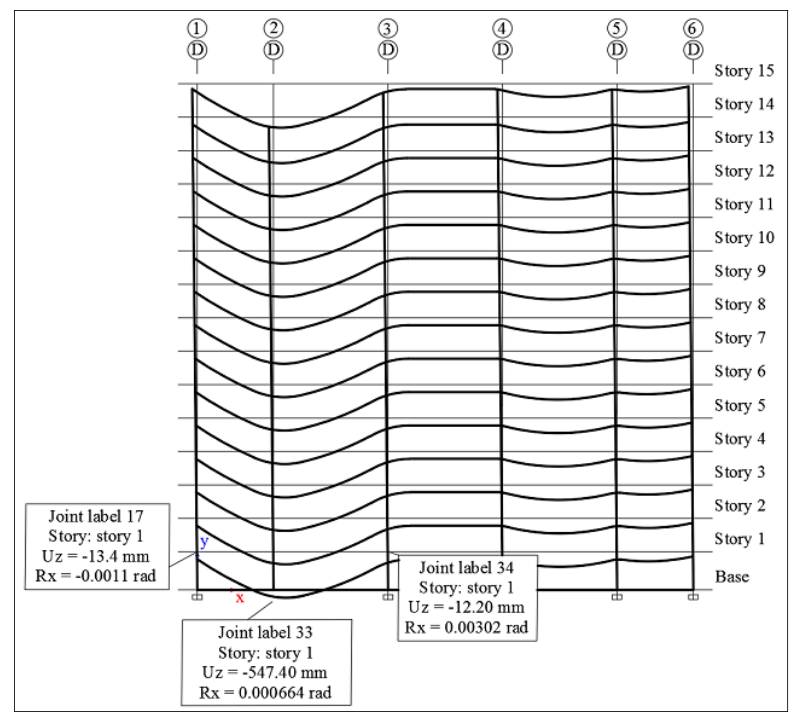

Figure 13. Displacement at notionally removed column D2 (part of grid line D) when moment frames are located at perimeters and along grid lines B, C, D, E, F and G (linear static analysis case 17).

Table 9 shows deformation responses when column D3 is notionally removed. Clearly, the conclusions are identical to when column D2 is notionally removed. Dynamic analysis predicted vertical displacement under notionally removed column D3 $(205.7 \mathrm{~mm})$, lower than when column D2 (212.1 mm) was notionally removed, due to continuity of the frame on either side of column D3. It is worthy to note that large vertical deformations at the location of the notionally removed column are typically accompanied by large axial forces and bending moments in the beams on each side of the notionally removed column. For catenary action to be effective, the moment-resisting connections joining these beams to the column face must be capable of resisting large rotations and axial forces [3]. Table 9 shows that for load cases 8,9 , and 10, the solutions do not converge at the location of the notionally removed column D3. This is due to a lack of continuity, as only shear connections are used internally.

Table 9. Comparison between displacements and rotations when interior column D3 is removed.

\begin{tabular}{ccccc}
\hline Case & $\begin{array}{c}\text { Displacement }(\mathbf{m m}) \\
\text { Joint 34 Elevation D }\end{array}$ & $\begin{array}{c}\text { Rotation (Radians) } \\
\text { Joint 34 Elevation D }\end{array}$ & $\begin{array}{c}\text { Rotation (Radians) } \\
\text { Joint 33 Elevation D }\end{array}$ & $\begin{array}{c}\text { Rotation (Radians) } \\
\text { Joint 35 Elevation D }\end{array}$ \\
\hline 8 & Very large & 0.000086 & -0.000005 & -0.0468 \\
9 & Very large & 0.000368 & 0.000083 & -0.0218 \\
10 & Very large & 0.000081 & 0.000065 & -0.0225 \\
20 & -528.70 & 0.000358 & -0.00247 & -0.000005 \\
21 & -649.70 & 0.000069 & -0.000942 & -0.000084 \\
22 & -205.70 & 0.000204 & -0.000780 & -0.000051 \\
\hline
\end{tabular}

Figures 14 and 15 show the response at failure for non-linear static analysis and non-linear dynamic analysis, respectively. Clearly, non-linear static analysis predicts much higher responses compared to non-linear dynamic analysis.

Column D1 is now selected as the notionally removed column. This column is part of the moment resisting frame; therefore, deformation responses converged for linear static and non-linear dynamic analyses where moment frames existed only in the perimeter. Non-linear static analysis, however, did not converge. When moment resisting frames are used in the perimeter as well as internally, Table 10 shows that the analysis converges with the non-linear dynamic analysis, producing more realistic results. Non-linear dynamic analysis (load case 25) predicts a vertical deformation of $88.2 \mathrm{~mm}$ at the location of notionally removed column D1, compared to $124.0 \mathrm{~mm}$ for non-linear static analysis 
and $225.5 \mathrm{~mm}$ for linear static analysis. Consistent with previous results in this paper, linear static and non-linear static analysis provide conservative estimates.

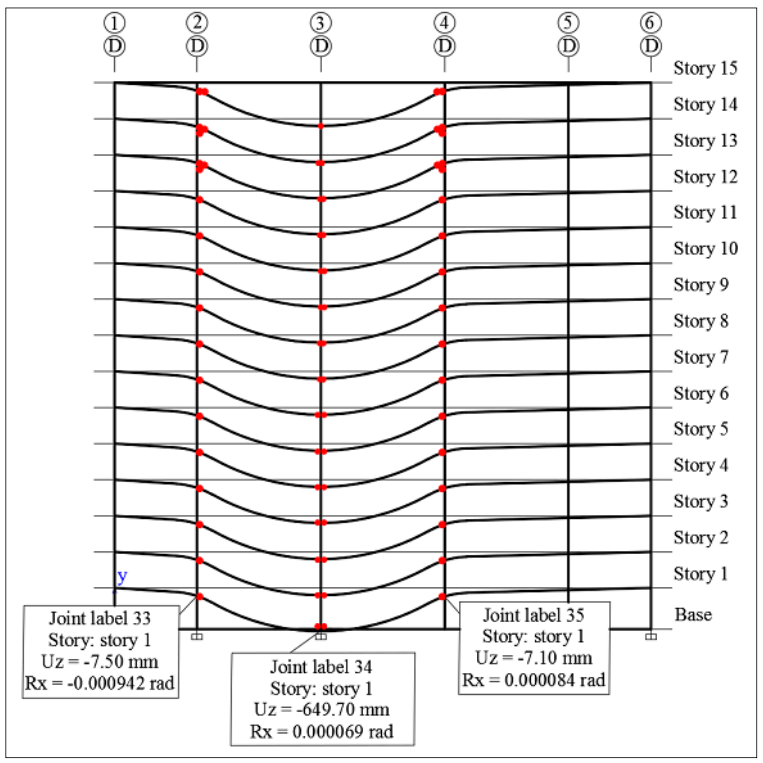

Figure 14. Displacement at notionally removed column D3 (part of grid line D) when moment frames are located at perimeters and along grid lines B, C, D, E, F and G (non-linear static analysis case 21).

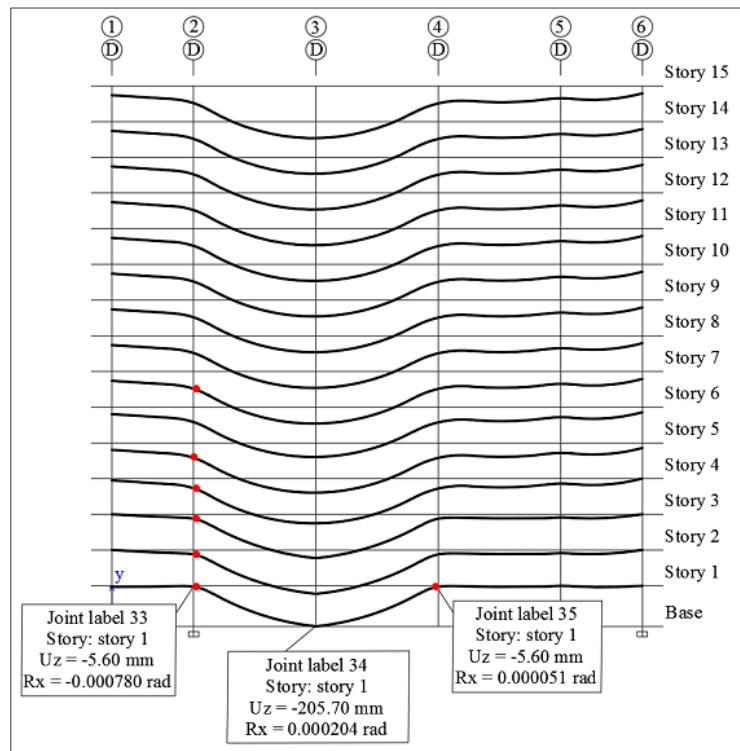

Figure 15. Displacement at notionally removed column D3 (part of grid line D) when moment frames are located at perimeters and along grid lines B, C, D, E, F and G (non-linear dynamic analysis case 22).

Table 10. Comparison between displacements and rotations when edge column D1 is removed.

\begin{tabular}{ccccc}
\hline Case & $\begin{array}{c}\text { Displacement (mm) } \\
\text { Joint 17 Elevation 1 }\end{array}$ & $\begin{array}{c}\text { Rotation (Radians) } \\
\text { Joint 17 Elevation 1 }\end{array}$ & $\begin{array}{c}\text { Rotation (Radians) } \\
\text { Joint 18 Elevation 1 }\end{array}$ & $\begin{array}{c}\text { Rotation (Radians) } \\
\text { Joint 16 Elevation 1 }\end{array}$ \\
\hline 11 & -500.40 & 0.000388 & -0.000336 & -0.000309 \\
12 & Very large & -0.000523 & -0.000228 & -0.000187 \\
13 & -206.40 & 0.000135 & -0.00020 & -0.000191 \\
23 & -225.50 & 0.000432 & 0.000019 & 0.000108 \\
24 & -124.00 & 0.000285 & -0.000039 & 0.000013 \\
25 & -88.20 & 0.000172 & -0.000029 & 0.000003 \\
\hline
\end{tabular}


Figure 16 shows the deformation response due to the notional removal of column D1 when moment frames are used at the perimeter only with a maximum vertical deformation of $206.4 \mathrm{~mm}$. Figure 17 shows that the maximum vertical response when moment frames are used internally is only $88.2 \mathrm{~mm}$. This indicates the structural stiffness for vertical deformation is higher when internal moment frames are used compared to the more flexible system with moment frames at the perimeter only. The flexible structure in Figure 16 shows a higher demand at beam ends as indicated by the number of plastic hinges compared to the stiffer system shown in Figure 17.

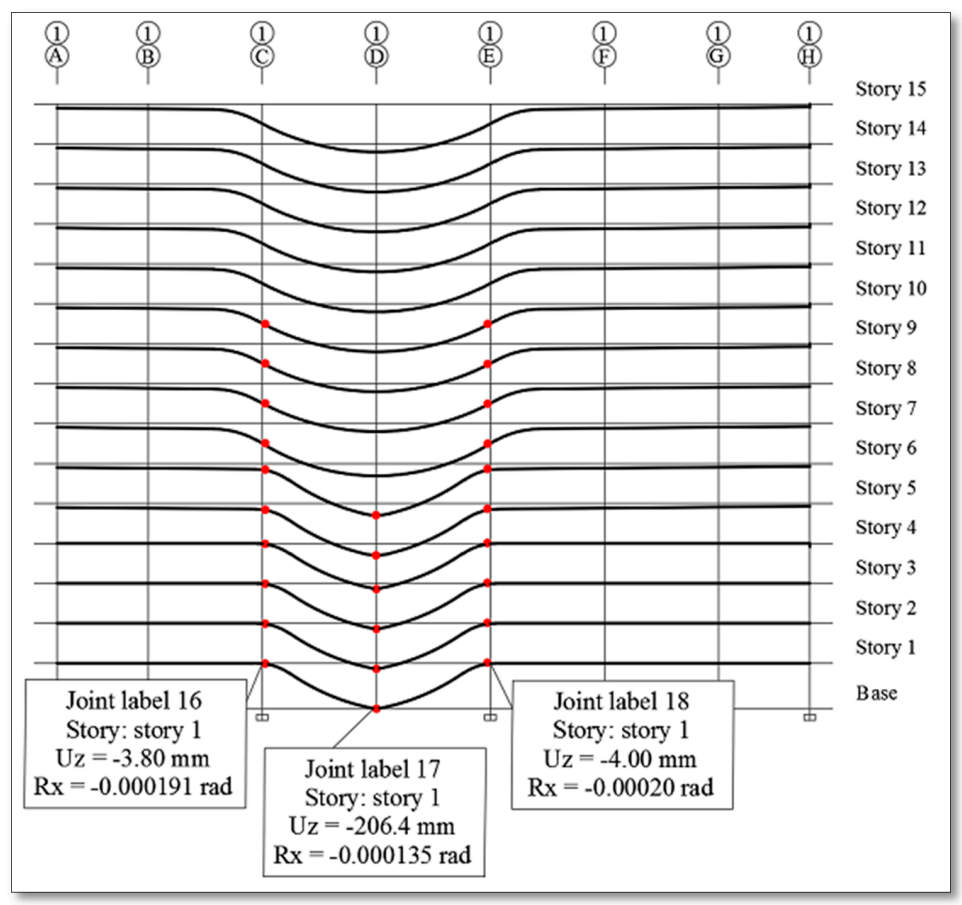

Figure 16. Displacement at the location of notionally removed column D1 when moment frames are located at perimeters only (non-linear dynamic analysis case 13).

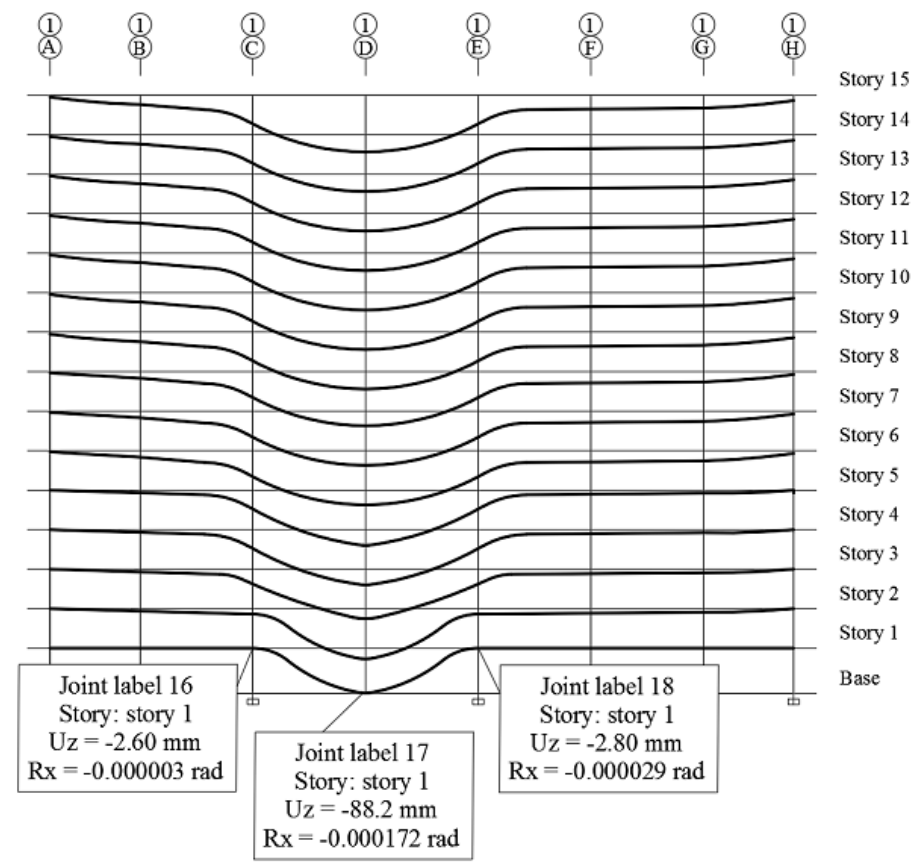

Figure 17. Displacement at the location of notionally removed column D1 when moment frames are located at perimeters and along grid lines B, C, D, E, F and G (non-linear dynamic analysis case 25). 


\section{Summary and Conclusions}

In this study, progressive collapse resistance of a steel framed structure was assessed based on the Alternate Path method (notional removal of columns) using linear static, non-linear static, and non-linear dynamic analysis methods. Two scenarios were examined: (1) moment resisting frames along the perimeter of the structure, and (2) moment resisting frames along perimeters and internally in one direction. These two scenarios are typical in the steel construction industry where the costlier moment resisting frames are used sparingly while various types of shear connections are preferred at all practical locations within the structural system due to their low cost. However, in the event of the loss of the primary load-carrying element, shear connections may not have the ability to transfer loads safely to the rest of the structural system. In linear and non-linear static analysis methods, dynamic effects are estimated using load increase factors. Conclusions related to the performance of moment resisting systems and analysis methods are summarized below.

- The response of the structure due to the notional removal of a corner column was best predicted using non-linear dynamic analysis compared to linear and non-linear static analysis methods. When moment resisting frames were located only at the perimeter of the building, non-linear static analysis predicted that the vertical deformation at the location of the notionally removed corner column was $63 \%$ of the vertical deformation computed using the linear static analysis method. Non-linear dynamic analysis predicted axial deformation at the location of the notionally removed corner column that was $40.4 \%$ of the vertical deformation computed using the linear static analysis method. Therefore, load increase factors used to estimate dynamic effects in linear and non-linear static analyses are conservative.

- Using perimeter as well as parallel internal moment frames reduces the lateral drift associated with the loss of corner columns compared to the drift occurring when moment frames are only located in the building perimeter.

- The use of additional internal moment resisting frames is expensive compared to restricting moment frames to the perimeter of the building as commonly desired. However, non-linear dynamic analysis predicted a vertical deformation when internal and perimeter moment frames are used at a notionally removed corner column to be $83 \%$ of the vertical deformation when moment resisting frames are restricted to the perimeter. Hence, use of internal moment frames decrease deformation demand when a corner was notionally removed. This results in safer structures exhibiting visible deformations in the event of a loss of a column.

- Although internal moment frames are recommended to increase the overall building stiffness and reduce deformation response, designers should consider using shear connections to connect beams to perimeter frames. This can decrease deformation demand and eliminate torsion from being induced into perimeter beams. Torsion on perimeter beams could potentially affect their plastic rotation capacity. In addition, beams framing into perimeter frames will probably be connected to the web of a column where moment connections are challenging to build.

- Shear connections used to connect gravity beams to internal columns are not capable of transferring load carried by notionally removed internal columns. No analysis methods converged with the removal of internal columns when no moment resisting frames were added internally.

- The use of internal moment resisting frames, in addition to perimeter moment frames, permits AP analysis to converge for all analysis methods. Non-linear dynamic analysis was more reliable and predicted vertical deformation at notionally removed internal column to be $38.7 \%$ of the vertical deformation predicted at the same location by linear static analysis.

- Non-linear static analysis may overestimate the deformation-controlled responses, leading to over-design, compared to non-linear dynamic analysis. 
Author Contributions: Conceptualization, O.M.; Methodology, O.M.; Software, O.M.; Validation, R.K. and O.M.; Formal Analysis, O.M.; Investigation, O.M.; Writing-Original Draft Preparation, O.M.; Writing-Review and Editing, R.K.; Visualization, R.K.; Funding Acquisition, O.M.

Funding: This research was funded by the Office of Research and Sponsored Programs (ORSP) under grant number 19300290".

Acknowledgments: In this section you can acknowledge any support given which is not covered by the author contribution or funding sections. This may include administrative and technical support, or donations in kind (e.g., materials used for experiments).

Conflicts of Interest: The authors declare no conflict of interest.

\section{References}

1. Department of Defense (DoD). Unified Facilities Criteria: Design Criteria to Resist Progressive Collapse UFC 4-023-03; DoD: Washington, DC, USA, 2016.

2. Mohamed, O. Progressive Collapse of Structures: Annotated Bibliography and Comparison of Codes and Standards. J. Perform. Constr. Facil. 2006, 20, 418-425. [CrossRef]

3. Dinu, F.; Marginean, I.; Dubinaab, D.; Petran, I. Experimental testing and numerical analysis of 3D steel frame system under column loss. Eng. Struct. 2016, 113, 59-70. [CrossRef]

4. Piluso, V.; Pisapia, A.; Castaldo, P.; Nastri, E. Probabilistic Theory of Plastic Mechanism Control for Steel Moment Resisting Frames. Struct. Saf. 2019, 76, 95-107. [CrossRef]

5. Mohamed, O. Assessment of Progressive Collapse Potential in Corner Panels of Reinforced Concrete Buildings. J. Eng. Struct. 2009, 31, 749-757. [CrossRef]

6. Kang, H.; Kim, J. Progressive Collapse of Steel Moment Frames Subjected to Vehicle Impact. J. Perform. Constr. Facil. 2014, 29. [CrossRef]

7. El-Tawil, S.; Li, H.; Kunnath, S. Computational Simulation of Gravity-Induced Progressive Collapse of Steel-Frame Buildings: Current Trends and Future Research Needs. J. Struct. Eng. 2014. [CrossRef]

8. Kwasniewski, L. Nonlinear dynamic simulations of progressive collapse for a multistory building. J. Eng. Struct. 2010, 32, 1229-1235. [CrossRef]

9. Kim, H.S.; Kim, J.; An, D. Development of integrated system for progressive collapse analysis of building structures considering dynamic effects. Adv. Eng. Softw. 2011, 40, 1-8. [CrossRef]

10. American Institute of Steel Construction (AISC). Steel Construction Manual, 14th ed.; AISC: Chicago, IL, USA, 2011.

11. Zolghadr Jahromi, H.; Izzuddin, B.A.; Nethercot, D.A.; Donahue, S.; Hadjioannou, M.; Williamson, E.B.; Engelhardt, M.; Stevens, D.; Marchand, K.; Waggoner, M. Robustness Assessment of Building Structures under Explosion. Buildings 2012, 2, 497-518. [CrossRef]

12. American Society of Civil Engineers (ASCE). ASCE 7-10. Minimum Design Loads for Buildings and other Structures (ASCE/SEI 7-10); ASCE: Reston, VA, USA, 2013.

13. Cassiano, D.; D'Aniello, M.; Rebelo, C.; Landolfo, R.; da Silva, L. Influence of seismic design rules on the robustness of steel moment resisting frames. Steel Compos. Struct. Int. J. 2016, 21, 479-500. [CrossRef]

14. Computers and Structures Inc. ETABS—Integrated Analysis, Design, and Drafting of Building Systems; Computers and Structures Inc.: Berkeley, CA, USA, 2013.

15. Song, B.I.; Sezen, H. Experimental and analytical progressive collapse assessment of a steel frame building. J. Eng. Struct. 2013, 56, 664-672. [CrossRef]

16. ASCE. ASCE 41. Seismic Rehabilitation of Existing Buildings (ASCE/SEI 41-06); ASCE: Reston, VA, USA, 2007.

17. Alashker, Y.; Li, H.; El-Tawil, S. Approximations in Progressive Collapse Modeling. J. Struct. Eng. 2011. [CrossRef]

18. Mohamed, O.A. Calculation of load increase factors for assessment of progressive collapse potential in framed steel structures. J. Case Stud. Struct. Eng. 2015, 3, 11-18. [CrossRef]

19. Kim, T.; Kim, J.; Park, J. Investigation of Progressive Collapse-Resisting Capability of Steel Moment Frames Using Push-Down Analysis. J. Perform. Const. Facil. 2009, 23, 327-335. [CrossRef]

20. Daneshvar, H.; Driver, R. Behavior of shear tab connections under column removal scenario. In Proceedings of the Structures Congress 2011, Las Vegas, NV, USA, 14-16 April 2011; American Society of Civil Engineers: Reston, VA, USA, 2011. 
21. Cassiano, D.; D'Aniello, M.; Rebelo, C. Parametric finite element analyses on flush end-plate joints under column removal. J. Constr. Steel Res. 2017, 137, 77-92. [CrossRef]

22. Mohamed, O.; Najmal, A.; Abbas, O. Impact of Seismic Design Criteria on Progressive Collapse Investigation. In Proceedings of the Tenth International Conference on Computational Structures Technology; Civil-Comp Press: Stirlingshire, UK, 2010; Paper No. 327; ISSN 1759-3433. 